\title{
DAMPAK REVOLUSI HIJAU DAN MODERNISASI TEKNOLOGI PERTANIAN: STUDI KASUS PADA BUDI DAYA PERTANIAN BAWANG MERAH DI KABUPATEN BREBES
}

\author{
Haryono Rinardi, ${ }^{* 1}$ Noor Naelil Masruroh, ${ }^{1}$ Nazala Noor Maulany, ${ }^{2}$ Yety Rochwulaningsih ${ }^{1}$ \\ ${ }^{1}$ Departemen Sejarah, Fakultas Ilmu Budaya, Univesitas Diponegoro, Semarang - Indonesia \\ ${ }^{2}$ Universitas Islam Negeri Mataram, Mataram - Indonesia \\ *Alamat korespondensi: rinardiharyono@yahoo.com
}

DOI:

Diterima/Received: 31 Januari 2019; Direvisi/ Revised: 8 Desember 2019; Disetujui/ Accepted: 11 Desember 2019

\begin{abstract}
Green Revolution is an effort to increase food production, especially in developing countries, by using agricultural modernization technology. This article identifies and evaluates some of the implementation impacts of technology modernization, in particular by taking a case study in the red onion cultivation in Brebes Regency. This study uses a historical method with a sociological approach that emphasizes the use of textual sources from newspapers and official reports, oral sources, and direct observation in the field. The results of this study found that through the Green Revolution, farmers were familiar with the use of artificial fertilizers, superior seeds, anti-pest pesticides, and so on. However, it led to high dependency on chemical fertilization, therefore production cost will be more inefficient. In the end, a large dependence of farmers also includes the fertilizer's companies, namely large companies that produce artificial fertilizers, pesticides and so on. In extreme terms, there is a new form of neo-colonialism in the cultivation system in developing countries.
\end{abstract}

Keywords: Green Revolution; Technology Modernization; Red Onion Cultivation.

\begin{abstract}
Abstrak
Revolusi Hijau merupakan salah satu upaya untuk meningkatkan produksi bahan pangan, khususnya di negara-negara yang sedang berkembang. Artikel ini mengidentifikasi dan mengevaluasi beberapa dampak dari implementasi modernisasi teknologi pertanian dalam budi daya pertanian, khususnya dengan mengambil studi kasus pada budi daya tanaman bawang merah di Kabupaten Brebes. Kajian ini menggunakan metode sejarah dengan pendekatan sosiologi yang menekankan pada penggunaan sumber tekstual dari koran maupun laporan resmi, sumber lisan, dan pengamatan langsung di lapangan. Hasil kajian ini menyatakan bahwa melalui Revolusi Hijau, petani mengenal penggunaan pupuk buatan, benih unggul, pestisida antihama, dan sebagainya. Akan tetapi, kemudian terjadi ketergantungan petani terhadap pemakaian pupuk buatan, pestisida antihama, dan benih unggul. Ujungnya terjadi ketergantungan petani yang besar kepada pihak luar, yaitu perusahaan besar yang memproduksi pupuk buatan, pestisida, dan sebagainya. Dengan istilah yang ekstrem terjadi bentuk neo-kolonialisme baru dalam sistem budi daya di negara-negara yang sedang berkembang.
\end{abstract}

Kata Kunci: Revolusi Hijau; Modernisasi Teknologi Pertanian; Budi daya Bawang Merah.

\section{PENDAHULUAN}

Burger (1962) dalam studinya menyebutkan bahwa wilayah pedalaman Jawa disulap menjadi produsen komoditas primer dalam perdagangan dunia sejak pertengahan abad XIX. Melalui penerapan Sistem Tanam Paksa yang dilanjutkan dengan eksploitasi secara liberal oleh para pengusaha perkebunan Jawa dalam kurun waktu kurang dari 50 tahun telah berkembang menjadi salah satu produsen komoditas perkebunan terbesar di dunia. 
Lebih dari satu abad kemudian kondisi mulai berbalik, pedalaman Jawa bukan lagi produsen utama komoditas primer dunia. Jawa masih menghasilkan komoditas beras sebagaimana dikenal sejak zaman pra-kolonial (Kartodirdjo \& Suryo, 1991: 20). Jawa masih menghasilkan beberapa komoditas perkebunan, tetapi sudah tidak lagi menjadi produsen utama dunia. Satu perbedaan yang mencolok adalah wilayah pedesaan di Jawa sejak akhir abad XX telah berubah menjadi konsumen bagi produk industri negara-negara berkembang. Pedesaan di Jawa menjadi konsumen bagi produk-produk pupuk buatan, pestisida antihama (dalam segala bentuk), benih unggul, dan sebagainya. Hal itu terjadi melalui proses Revolusi Hijau yang berlaku di Indonesia sejak awal 1970-an. Melalui Revolusi Hijau petani dikenalkan dengan pupuk buatan, pestisida anti hama, benih unggul, sistem budidaya pertanian yang baru, sistem irigasi bagi lahan sawah untuk budi daya pertanian pangan dan hortikultura, dan penyediaan kredit bagi para petani peserta program Revolusi Hijau. Dengan kata lain, Revolusi Hijau merupakan modernisasi pertanian pada petani di Jawa. Melalui Revolusi Hijau petani dikenalkan kepada sistem budi daya yang baru dengan memanfaatkan benih unggul, pupuk buatan, pestisida antihama, dan pemanfaatan kredit sebagai modal awal bagi petani dalam sistem budi daya baru.

Revolusi hijau dengan memanfaatkan teknologi baru pertanian, produksi pertanian di Jawa jelas mengalami peningkatan. Petani terampil mengadaptasi sistem budi daya baru dalam berbagai jenis tanaman. Akan tetapi, di balik itu semua terjadi ketergantungan yang besar oleh petani terhadap beragam produk yang berasal dari para pemilik modal dalam dunia pertanian. Budi daya tanaman bukan lagi diusahakan secara tradisional dengan memakai ikatan desa sebagai penggeraknya (Burger, 1962: 114). Sistem kapitalis sudah menggantikan sistem tradisional, upah tunai menggantikan hubungan tradisional pedesaan. Sistem budi daya tradisional tanaman digantikan oleh sistem modern yang membutuhkan modal besar dalam mengawali budi daya beragam tanaman. Kondisi itu jelas berbeda dari yang terjadi pada pertengahan abad XIX yang lalu, yang lebih mengutamakan ikatan desa dalam produksi pertanian di pedesaan.

Dalam sistem budi daya yang baru petani dipacu untuk mendapatkan keuntungan besar dari tanamannya. Hal itu karena sebelumnya mereka harus mengeluarkan dana besar guna membeli benih unggul, pupul buatan, membayar upah buruh tani, membeli pestisida antihama, dan sebagainya. Dengan kata lain, petani telah mengeluarkan sejumlah dana untuk memulai budi daya tanamannya. Oleh karena itu, mereka harus memperoleh keuntungan besar agar tidak mengalami kerugian karena pengeluaran untuk modal awal bagi budi daya tanamannya. Dengan demikian, sistem kapitalis telah berkembang semakin dalam di pedesaan di Jawa sejak pertengahan 1970-an. Sistem kapitalis tidak hanya merambah pada tingkat pemilik modal yang mendorong produksi petani, tetapi sudah menjalar pada tingkat pelaksanaan budi daya pertanian. Apabila pada abad XIX sistem kapitalis seakanakan hanya bertindak sebagai sponsor dalam budi daya berbagai tanaman di Jawa. Keadaan itu sudah berubah pada pertengahan 1970-an, sistem kapitalis sudah merasuk ke dalam kehidupan pedesaan di Jawa.

Kapitalisasi di pedesaan Jawa sejak 1970-an, ternyata tidak berimbas pada peningkatan kesejahteraan petani. Produk pertanian memang mengalami peningkatan, tetapi kesejahteraan petani secara keseluruhan mengalami penurunan. Hasil yang paling berarti sebagai akibat pelaksanaan Revolusi Hijau adalah adanya pengaruh positif bagi produktivitas tanaman pangan di Indonesia. Sejak kemunculan program itu, produksi beras telah meningkat dibandingkan dengan sebelumnya. Hal yang lebih penting lagi, Revolusi Hijau telah menjadikan Indonesia berswasembada beras pada periode 1980 -an. Suatu hasil yang patut dibanggakan oleh sebuah negeri yang sebelumnya merupakan pengimpor beras terbesar. Revolusi Hijau ternyata menyebabkan petani kaya makin kaya, karena mengalami peningkatan pendapatan (Sajogyo, 1977: 15). Hal yang sebaliknya dialami petani gurem, yang bukannya menjadi lebih sejahtera, tetapi justru semakin bertambah berat beban hidupnya (Sajogyo, 1977: 4). Dengan demikian, tercipta 
kesenjangan sosial yang semakin bertambah luas, jurang antara si kaya dan si miskin bukan semakin sempit, tetapi justru bertambah lebar (Sujono dan Birowo, 1976: 26).

Dengan latar belakang seperti diuraikan di atas, artikel ini memberikan argumentasi bahwa Revolusi Hijau bukannya mendatangkan kemakmuran tetapi justru menciptakan kemiskinan bagi petani kecil. Secara umum modernisasi pertanian telah meningkatkan produksi pertanian bagi para petani di negaranegara yang sedang berkembang, tetapi di balik itu justru tercipta kesenjangan antara petani kaya dan miskin (Syamsudin \& Hasrida, 2019: 2). Petani kaya merupakan pihak yang menikmati modernisasi pertanian. Sebaliknya, bagi petani kecil modernisasi pertanian adalah bencana bagi mereka. Oleh karena itu, pengaruh modernisasi pertanian terhadap petani bawang merah di daerah Brebes menarik untuk dikaji. Beberapa pertanyaan yang muncul adalah bagaimana modernisasi pertanian berlaku di kalangan petani bawang merah. Apakah modernisasi pertanian berdampak positif atau negatif. Selanjutnya, bagaimana hal tersebut dapat terjadi.

\section{METODE}

Metode yang digunakan dalam penelitian ini adalah metode sejarah, dimulai dari heuristik yaitu proses menemukan dan mengumpulkan sumber, baik primer maupun sekunder (Garraghan, 1957: 33; Gottschalk, 1975: 32; Notosusanto, 1978: 11). Sumber primer dalam kajian ini diperoleh dari sumber resmi pemerintah, misalnya Laporan Tahunan Bank Indonesia. Laporan Tahunan Bank Indonesia diperoleh pada Perpustakaan Bank Indonesia. Melalui Laporan Tahunan Bank Indonesia dapat diketahui perkembangan produksi tanaman pangan dan hortikultura di Indonesia. Sumber primer lainnya adalah sumber lisan, yaitu narasumber yang merupakan petani dan pedagang bawang merah di Brebes. Keterangan mereka sangat penting untuk mengungkapkan seluk beluk budi daya bawang merah dan perdagangan bawang merah di tingkat petani.
Langkah kedua dalam metode sejarah adalah kritik sumber. Ada dua jenis kritik dalam metode sejarah, yaitu kritik intern dan ekstern. Kritik intern digunakan untuk menjawab kredibilitas sebuah dokumen, sehingga berkaitan dengan isi sebuah dokumen. Sementara itu, kritik ekstern berhubungan dengan bahan dokumen atau otentisitas dokumen atau sumber. Hasil kritik sumber adalah fakta, dalam sejarah ada dua golongan fakta: fakta keras, yaitu fakta yang kebenarannya tidak diragukan lagi; dan fakta lunak, yaitu fakta yang kebenarannya masih dapat diperdebatkan. Fakta yang didapat dalam kritik sumber adalah Revolusi Hijau merupakan modernisasi pertanian sejak awal 1970-an. Fakta lain yang diperoleh adalah terdapat banyak jenis pekerjaan dalam budi daya bawang merah di Brebes.

Langkah ketiga dalam metode sejarah adalah interpretasi atau tafsir fakta. Dalam hal ini ada dua cara. Pertama, analisis atau menguraikan fakta. Kedua, dengan cara sintesis atau menyatukan fakta (Pranoto, 2014: 55-56). Langkah terakhir adalah historiografi atau menuliskan fakta secara sistematis agar mudah dipahami dan dibaca.

\section{REVOLUSI HIJAU: SEBUAH POGRAM MODERNISASI PERTANIAN DI INDONESIA}

Revolusi Hijau adalah sebutan tidak resmi yang digunakan untuk menggambarkan perubahan fundamental dalam pemakaian teknologi pertanian, khususnya pertanian pangan di berbagai negara yang sedang berkembang, khususnya di Asia. Revolusi Hijau muncul ketika banyak negara yang sedang berkembang sering kali mengalami kesulitan bahan pangan. Kondisi itu mendorong Yayasan Ford dan Rockfeller untuk mengembangkan budi daya gandum dan padi dengan teknologi yang baru, yaitu dengan memakai benih unggul, pupuk kimia, pestisida antihama, dan sistem pengairan yang baik. Semua itu merupakan hal yang baru dalam budidaya tanaman pangan bagi para petani tradisional. Tujuannya adalah untuk meningkatkan produksi 
bahan pangan, sekaligus menambah kesejahteraan petani. Konsep Revolusi Hijau itu di Indonesia kemudian dikenal sebagai Program Bimbingan Massal (Bimas).

Pada pelaksanaannya di Indonesia, Revolusi Hijau berawal dari kegiatan praktik lapangan mahasiswa Institut Pertanian Bogor (IPB) dengan tujuan memperkenalkan Panca Usaha Tani. Kegiatan itu dilakukan selama satu bulan menjelang musim tanam. Pada 1963-1964 kegiatan itu lebih difokuskan melalui Demonstration Plot (Demplot) di Karawang. Hasilnya berupa kenaikan produksi rata-rata sebanyak 74,72 kw/hektare padi basah dibandingkan dengan 31,98 kw/hektare padi pada persawahan biasa (Bank Negara Indonesia Unit I, 1967: 153). Berdasar kondisi itu, sejak periode 1964-1965 pola Demplot ini dikembangkan melalui uji coba di berbagai provinsi (Humas BRI, 1995: 59). Sistem itu kemudian ditetapkan sebagai usaha pemerintah untuk meningkatkan produksi padi yang dikenal dengan nama Bimas (Bank Negara Indonesia, 1967: 153-154).

Kemudian, usaha itu dikembangkan oleh Pemerintah Orde Baru menjadi suatu kegiatan penyuluhan massal, yang bertujuan untuk meningkatkan produksi pertanian dengan cara intensifikasi guna meningkatkan kesejahteraan petani (SK Menteri Pertanian No. 546/kpts/12/org/1969). Program itu merupakan usaha bimbingan bersama dari berbagai instansi pemerintah, baik di dalam maupun di luar lingkungan Departemen Pertanian, ke arah swadaya masyarakat tani dengan jalan Panca Usaha, pembinaan, pengolahan dan pemasaran hasil pertanian, dan terakhir pembangunan masyarakat desa (Sangging et al., 1990: 27). Panca Usaha meliputi usaha-usaha pengurusan pengairan yang baik, penggunaan bibit unggul, penggunaan pupuk, pemberantasan hama penyakit dan penggunaan cara-cara bercocok tanam yang tepat. Semuanya itu disebut sebagai Sapta Usaha (Tjitropranoto, 1977: 193). Dengan demikian, jelas bahwa Revolusi Hijau yang dijabarkan ke dalam Program Panca Usaha Tani merupakan modernisasi pertanian di Indonesia. Hal itu semakin jelas dengan memperlihatkan salah satu hal yang diharapkan dicapai melalui program itu, yaitu menstimulasi pengembangan industri pertanian seperti pupuk, obat-obatan, peralatan pertanian, dan sebagainya.

Dalam pelaksanaannya karena pada umumnya petani di Indonesia merupakan petani kecil dengan lahan yang terbatas dan modal yang kecil, dan dianggap tidak bankable (Hartono, 1996: 1), maka diperlukan kredit dari pemerintah. Faktor lainnya adalah modernisasi pertanian membutuhkan biaya yang tidak sedikit bagi petani untuk memulai usaha pertaniannya. Dana itu digunakan untuk membeli benih unggul, pupuk buatan, pestisida anti hama, dan biaya perawatan tanaman. Semuanya membutuhkan dana yang tidak kecil, suatu kondisi yang berbeda dibanding sistem budi daya padi pada masa sebelumnya. Dana yang diperoleh dari kredit digunakan petani untuk membeli sarana produksi pertani-an (Saprodi). Semuanya itu dibutuhkan untuk penerapan teknologi baru bagi petani. Pada awalnya, kredit hanya diterima petani sebagai insentif karena mengadopsi teknologi baru dalam rangka menaikkan produksi beras. Selanjutnya, kredit juga diberikan untuk berbagai macam tanaman palawija, termasuk jagung, kedelai, kacang tanah, padi gogo, sorgum dan kacang hijau (Bank Indonesia, 2001: 21).

Dengan adanya perubahan besar dalam sistem budi daya bahan pangan tersebut, hasilnya segera dapat diketahui. Indonesia bahkan sempat mengalami swasembada beras dalam periode 1984-1989. Melalui modernisasi pertanian terjadi peningkatan rata-rata produksi padi untuk setiap hektarenya di Indonesia selama periode 19701985. Produktivitas lahan persawahan telah meningkat dari 26,01 kuintal/hektare pada 1971 menjadi 39,42kuintal/hektare pada tahun 1985. Dengan demikian selama kurun waktu lima belas tahun terjadi peningkatan produktivitas lahan persawahan sebesar 13,41 kuintal/hektare untuk setiap tahun. Dengan kata lain, secara nasional setiap tahun produksi padi telah meningkat sebesar 0,894 kuintal untuk setiap hektarenya, yang semuanya disebabkan oleh modernisasi pertanian. Kenaikan produksi padi di Indonesia sebagai hasil modernisasi pertanian membawa pengaruh digunakannya pupuk buatan secara meluas oleh petani Indonesia. Apabila pada tahun 1970 rata- 
rata pupuk buatan hanya digunakan sebanyak 101 $\mathrm{kg} /$ hektare. Kemudian, angka itu meningkat menjadi $343 \mathrm{~kg}$ untuk setiap hektarenya. Kondisi itu membawa konsekuensi yang lebih luas lagi, yaitu meningkatnya kebutuhan pupuk buatan di kalangan petani Indonesia. Hal itu memaksa pemerintah kemudian membangun industri petrokimia, termasuk pupuk buatan secara besarbesaran. Hasilnya produksi pupuk buatan Indonesia melonjak dari 103 ribu ton di tahun 1970 menjadi 3,5 juta ton pada tahun 1985 (Booth, 1988: 150).

Hasil positif modernisasi pertanian dapat diketahui jika membandingkannya secara langsung dengan sistem budidaya tradisional. Bersama dengan Program Intensifikasi Massal (Inmas), hasil rata-rata lahan persawahan untuk setiap hektarnya selama periode tahun 1970-1977 adalah sekitar 60\% lebih tinggi dibandingkan dengan lahan persawahan yang tidak mengikuti program intensifikasi. Dengan demikian, program intensifikasi pertanian yang merupakan kombinasi penggunaan penyuluhan terpadu, pemakaian bibit unggul, pupuk buatan, obat antihama, dan kredit bagi petani peserta untuk membeli semua Saprodi telah mampu meningkatkan hasil produksi padi. Jadi, kenaikan produksi padi di Indonesia merupakan hasil dari intensifikasi pertanian.

\section{MODERNISASI PERTANIAN DAN KEMISKINAN PETANI}

Modernisasi pertanian ternyata menyebabkan petani kaya makin kaya, karena mengalami peningkatan pendapatan (Sajogyo, 1977: 15). Hal yang sebaliknya dialami petani gurem, yang bukannya menjadi lebih sejahtera, tetapi justru semakin bertambah berat beban hidupnya (Sajogyo, 1977: 4). Dengan demikian, tercipta kesenjangan sosial yang semakin bertambah luas; jurang antara si kaya dan si miskin bukan semakin sempit, tetapi justru bertambah lebar (Sujono \& Birowo, 1976: 26).

Fenomena itu disebabkan hanya petani kaya yang dapat menikmati dan memanfaatkan kredit mudah dan murah, sehingga dapat menerapkan teknologi yang mahal dalam sistem budi daya pertanian yang baru. Hal itu karena, petani kaya merupakan kelompok pertama yang dihubungi pemerintah setempat dan para penyuluh pertanian untuk menyampaikan informasi tentang jenis padi baru yang dapat menghasilkan produksi lebih banyak. Pada umumnya petani kaya mempunyai hubungan pribadi yang lebih dekat dengan para pejabat desa, sehingga mereka merupakan kelompok pertama yang mendapatkan informasi dari aparat desa mengenai berbagai macam hal, termasuk di antaranya teknologi baru di bidang budi daya padi (Wawancara dengan Wage, 21 Juli 2019).

Hal yang sebaliknya terjadi pada petani gurem. Sempitnya lahan yang dimiliki menyebabkan pendapatan menjadi sangat rendah, maka bagi mereka penerapan teknologi baru dalam budi daya padi dianggap sebagai sebuah risiko yang besar. Dengan dasar pandangan itu, pada awal pelaksanaan modernisasi pertanian mereka bersikap acuh tak acuh (Tjitropranoto, 1977: 189), enggan dan tidak mempunyai kemauan dan berangsur-angsur ikut serta, kadang dengan paksaan. Kondisi itu disebabkan petani kecil pada umumnya hanya memiliki lahan di bawah 0,5 hektare, maka sangat riskan untuk mencoba sesuatu yang baru. Hal itu menyebabkan kegagalan dalam satu kali panen yang berarti petani tidak memiliki apa-apa lagi selama satu musim berikutnya. Keadaan itulah yang menyebabkan petani kecil selalu menghindari risiko. Oleh karena itu, naluri dasar petani adalah meniru. Mereka hanya bersedia menerima teknologi atau cara budi daya baru jika benar-benar terbukti berhasil meningkatkan hasil panen. Dengan demikian, petani kecil hanya dapat mengikuti petani lainnya yang telah mencapai keberhasilan. Keadaan itu menyebabkan petani kecil tidak memperoleh hasil maksimal dalam Program Revolusi Hijau. Kondisi itu menyebabkan mereka menjadi peserta yang ketinggalan dalam penggunaan dan pemanfaatan teknologi baru yang diperkenalkan melalui revolusi hijau (Sajogyo, 1977: 16). Dengan kata lain, mereka baru terlibat dalam modernisasi pertanian, ketika program itu sudah berjalan beberapa tahun. Di samping itu, karena kondisi ekonominya, mereka biasanya justru menyewakan 
lahannya kepada orang lain. Dia sendiri kemudian bekerja sebagai buruh yang menerima upah di sawahnya sendiri (Rahardjo, 1984: 23). Hal itu menyebabkan petani gurem pada hakikatnya tidak merasakan bantuan kredi dan pengaruh perubahan penggunaan teknologi terhadap budi daya padi.

Kredit pertanian bagi petani gurem itu sesungguhnya bukan berkah tetapi musibah. Keadaan itu akan semakin lebih menyedihkan lagi bagi buruh tani yang tidak bertanah. Walaupun masih diterima memburuh di sawah, namun kondisinya sudah sangat berbeda dibandingkan dengan pada masa sebelum ada modernisasi pertanian. Oleh karena dipakainya teknologi baru dalam budi daya padi, tenaga mereka tidak lagi banyak dibutuhkan seperti pada masa sebelumnya. Sebagai akibatnya, upah mereka cenderung tertinggal, bahkan di sebagian wilayah Jawa upahnya tertinggal sampai $30 \%$ selama beberapa tahun. Dengan demikian, kredit pertanian bukannya membantu petani kecil dan buruh tani, tetapi justru menyebabkan penderitaan. Hal itu disebabkan beberapa faktor. Pertama dengan adanya modernisasi pertanian terjadi perubahan dalam tingkah laku produksi padi. Apabila sebelum ada modernisasi pertanian, setiap penduduk desa mempunyai hak ikut serta dalam proses penanaman dan panen padi di desanya. Setelah adanya modernisasi, pemilik tanah mempunyai kemampuan untuk membatasi dan memilih tetangga terdekat untuk dapat ikut serta dalam proses penanaman dan panen padinya (Collier et al., 1982: 96-97). Kondisi itu disebabkan oleh dua faktor. Faktor pertama, penggunaan pupuk buatan yang diperoleh melalui kredit telah menyebabkan petani pemilik lahan mulai bersifat 'tamak'. Mereka dituntut untuk mengembalikan kredit yang telah diterimanya, sehingga lahan pertaniannya diusahakan lebih produktif dan memberi hasil yang maksimal. Kondisi itu membuat mereka melalaikan kewajiban tradisionalnya, karena para pemilik tanah dapat mengandalkan sumber kekuatan baru menggantikan ikatan tradisional yang dahulunya digunakan bersama-sama. Sanksi sosial desa tidak dapat lagi dipakai untuk memaksa para pemilik lahan menyewa tetangganya bekerja di sawahnya (Temple, 1976: 24-25).
Keuntungan material menjadi kepen-tingan utama pemilik lahan dan orang kaya di desa. Sistem kerja tradisional mulai digantikan oleh sistem kerja komersial. Faktor kedua, mekanisasi dan teknik baru dalam budi daya padi, diikuti dengan perubahan penggunaan alat panen yang jauh lebih efisien telah menyebabkan berkurangnya kebutuhan terhadap tenaga kerja dalam proses budidaya maupun panen padi (Jones, 1984: 147). Sebagai akibatnya, posisi pemilik sawah menjadi lebih kuat dibandingkan dengan buruh tani. Konsekuensinya, buruh tani harus menerima lebih banyak beban pekerjaan dibandingkan periode sebelumnya, dengan upah yang tetap bahkan cenderung berkurang.

Faktor kedua, petani gurem tidak menekuni sawahnya secara maksimal karena sempitnya lahan. Mereka mempunyai pekerjaan sambilan di luar sektor pertanian, sehingga hasil sawahnya tidak optimal. Selain itu, ada kebiasaan untuk mengurangi takaran pupuk, sehingga jumlah yang digunakan tidak sesuai dengan anjuran. Sisanya dijual untuk menambah biaya hidup. Kredit yang didapat tidak otomatis digunakan bagi kepentingan usaha tani, tetapi untuk keperluan lain. Oleh karena itu, mereka tidak merasakan manfaat positif pelaksanaan Revolusi Hijau dan penerapan teknologi pertanian dalam budi daya padi. Dengan demikian, program intensifikasi pada petani kecil nyaris tidak memiliki pengaruh bagi kehidupannya (Kompas, 28 Februari 1978).

Faktor ketiga, dalam kasus tertentu ditemukan para penerima kredit yang kemungkinan tidak mampu membayar kembali pinjaman yang diterimanya (Staub, 1977: 35.) Mereka itu adalah para petani kecil yang sering kali mencapuradukkan kredit yang sifatnya produktif dengan kredit konsumtif. Keberadaan kredit pertanian dalam pelaksanaan Revolusi Hijau dengan penerapan teknologi pertanian sering kali digunakan untuk menutupi kebutuhan lainnya. Masalah muncul ketika mengalami gagal panen. Permasalahan itu muncul dalam kasus serangan wereng yang dahsyat di Jawa selama periode 19751976. Banyak petani kecil yang tidak mampu mengembalikan pinjamannya karena serangan wereng tersebut. Akibatnya kredit pertanian yang mereka terima berubah menjadi musibah, bukan 
anugerah. Mereka itu, dikejar-kejar birokrat desa dan petugas BRI karena kredit pertanian yang merupakan bagian Revolusi Hijau belum dilunasi.

Keadaaan yang sebaliknya terjadi pada petani besar dan kaya. Mereka lebih diuntungkan dengan program Revolusi Hijau dengan penerapan teknologi pertaniannya (Arndt, 1994:120). Melalui penerapan teknologi baru di bidang budi daya padi, usaha tani menjadi lebih efisien dibandingkan dengan cara tradisional. Program Revolusi Hijau dengan penerapan teknologi pertanian telah mengurangi sistem kerja padat karya yang diterapkan dalam sistem tradisional. Dengan demikian, yang diuntungkan adalah petani kaya yang memiliki banyak lahan sawah produktif. Petani miskin yang tidak memiliki tanah justru kehilangan kesempatan kerja karena penerapan sistem budi daya padi yang lebih efisien. Bersamaan dengan itu, adanya penerapan teknologi pertanian dalam Revolusi Hijau telah membuka peluang baru di bidang ekonomi kepada petani kaya. Mereka bukan saja menjadi petani atau pedagang, tetapi mengembangkan usaha menjadi pengusaha penggilingan beras. Semua itu disebabkan keberhasilannya untuk meningkatkan produksi padi.

Dengan perkembangan yang seperti di atas menyebabkan turunnya tingkat kesejahteraan petani, khususnya petani kecil dan buruh tani. Berdasar pada data yang ada diketahui bahwa pada 1970, golongan miskin di pedesaan (berpenghasilan setara nilai antara 4,4 kg dan 3,3 kg beras) adalah sebesar $61 \%$ dari seluruh penduduk Jawa, maka dalam tahun 1976 angkanya turun menjadi $59 \%$, sedangkan untuk luar Jawa turun dari 45\% menjadi $42 \%$. Berdasar data di atas, sepintas ada perbaikan dalam pengurangan jumlah penduduk miskin. Akan tetapi, gambaran itu berubah jika perhatian diarahkan kepada golongan yang paling miskin, yaitu yang berpenghasilan setara dengan nilai beras sebesar 2,5 kg ke bawah. Persentase penduduk yang paling miskin telah meningkat dari 21\% menjadi 25\% (Rahardjo, 1984: 38). Dengan demikian, jumlah penduduk miskin bukannya turun, tetapi justru meningkat.

Indikasi peningkatan jumlah petani miskin dapat dilihat dari sebaran luas tanah yang dimiliki petani sebelum dan selama pelaksanaan Bimas. Setelah Bimas dijalankan, terjadi pergeseran persentase kepemilikan lahan pertanian di pedesaan Jawa pada periode 1973-1978. Apabila pada 1973 persentase kepemilikan lahan 0,10-0,25 hektare mencapai 26\%, maka pada 1983 persentase kelompok tersebut tinggal $17 \%$. Ada dugaan bahwa penurunan kepemilikan lahan persawahan yang kurang dari $0,25 \%$ disebabkan lahan itu terserap ke dalam kelompok 0,25-0,50 hektare (Abdullah et al., 1995: 3). Dugaan itu diperkuat dengan peningkatan rumah tangga tani yang tidak memiliki tanah pada periode yang sama. Apabila pada 1973 prosentase petani yang tidak memiliki tanah mencapai $12,1 \%$, maka pada 1980 jumlah keseluruhan bertambah mencapai 14,9\% (Rahardjo, 1984: 44). Dengan kata lain, jumlah rumah tangga tani yang tidak memiliki lahan pertanian semakin meningkat, justru setelah Program Bimas berjalan.

\section{KETERGANTUNGAN PETANI BAWANG MERAH DI BREBES}

Budi daya bawang merah sudah dilakukan oleh petani Brebes sejak lama. Beberapa sumber memberi informasi, bahwa kegiatan budi daya bawang merah yang saat ini mereka lakukan, sudah dilakukan selama tiga generasi sebelumnya. Sebagaimana dengan petani padi, mereka juga menggunakan pupuk buatan dan pestisida antihama. Hal itu dilakukan agar tanamannya menjadi lebih subur dan terbebas dari serangan hama yang dapat merusak tanaman. Akan tetapi, dalam perkembangannya penggunaan pupuk buatan dan pestisida anti-hama semakin lama semakin menjerat petani bawang merah. Mereka tidak hanya menggunakan pupuk buatan dan pestisida antihama, tetapi juga telah tergantung pada kedua sarana produksi tersebut. Hal itu dapat diketahui dari jumlah takaran pupuk buatan yang dipakai oleh petani dalam budi daya bawang merah. Apabila pada periode 1970-1980-an petani bawang merah hanya mengenal urea dan ZA sebagai pupuk untuk tanamannya, maka memasuki abad XXI, mereka telah mengenal berbagai jenis pupuk buatan yang digunakan petani untuk budi 
daya bawang merah. Pupuk yang digunakan adalah SP36, Urea, ZA, KCl, dan NPK, serta pupuk yang diracik sendiri oleh petani. Tanpa beragam pupuk buatan itu, petani bawang merah mempercayai bahwa hasil panen tanamannya akan turun. Hal itu yang mendorong mereka menggunakan pupuk buatan dalam jumlah dan takaran yang lebih besar.

Kondisi serupa juga terjadi pada penggunaan pestisida antihama, yang saat ini jumlahnya terus bertambah dibandingkan dengan pada 1970-an, ketika Revolusi Hijau baru berjalan. Apabila pada periode 1970-an, pestisida antihama digunakan hanya sebagai endrin, maka pada saat ini menjadi kebutuhan pokok rutin yang harus selalu diberikan pada tanaman bawang. Terdapat berbagai jenis pestisida anti-hama yang dipakai petani untuk melindungi tanamannya dari serangan hama perusak bawang merah. Petani terpaksa memakainya karena tanpa pestisida itu, tanamannya terancam gagal panen.

Jumlah penggunaan pupuk buatan dan pestisida antihama yang semakin meningkat, dilataberlakangi oleh dua hal. Pertama, adanya ketergantungan petani terhadap pemakaian kedua jenis saprodi itu. Kedua, terkait dengan kemudahan petani untuk mendapatkan pupuk buatan dan pestisida anti-hama. Pada masa awal Revolusi Hijau, yaitu periode 1970-an, untuk mendapatkan pupuk buatan dan pestisida hanya dapat diperoleh jika terlibat dalam Program Bimas. Dalam hal ini, petani hanya akan mendapatkan pupuk buatan dan pestisida dari KUD atau toko resmi yang ditunjuk oleh pemerintah. Dengan demikian, tidak mudah untuk mendapatkan kedua jenis sarana produksi itu. Hal itu disebabkan pupuk buatan dan pestisida pada saat itu sebagian besar masih diimpor, sehingga distribusinya diatur secara ketat oleh pemerintah. Kondisi demikian menyebabkan kedua jenis sarana produksi tersebut tidak mudah diperoleh di pasaran. Pada saat yang bersamaan, secara psikologis petani juga belum tahu dan mengenal manfaat serta kegunaan pupuk buatan dan pestisida. Oleh karena itu, mereka masih ragu-ragu dalam memakai pestisida dan pupuk buatan dalam budi daya tanamannya. Lebih dari itu, petani bahkan perlu diyakinkan dan dibujuk oleh Petugas Penyuluh Lapangan (PPL) untuk menggunakan pupuk buatan dan pestisida.
Situasi itu tidak lagi berlaku sejak awal 1990an, bahkan keadaannya sudah berbalik 180 derajad. Petani tidak lagi perlu dibujuk dan diyakinkan untuk memakai pupuk buatan dan pestisida. Mereka sudah mengenal dan mengetahui manfaat serta kegunaan kedua jenis Saprodi itu. Hal itu disebabkan bawang merah pada dasarnya merupakan tanaman yang banyak membutuhkan hara, baik pada masa pertumbuhan vegetatif maupun pada saat pembentukan, pembesaran, dan pematangan umbi. Besarnya kebutuhan pupuk buatan pada bawang merah karena tanaman itu banyak menyerap unsur hara makro dari dalam tanah seperti Nitrogen $(\mathrm{N})$, Phosphor (P) dan Kalium (K). Namun unsurunsur tersebut tidak selalu tersedia di dalam tanah disebabkan sistem budi daya yang terus-menerus dilakukan. Hal yang menarik adalah dalam budi daya bawang merah diperlukan frekuensi pemupukan minimal tiga kali dalam satu kali masa tanam, yaitu pada saat pengolahan lahan dan pemeliharaan tanaman. Pemupukan pertama diberikan bersama ketika pengolahan tanah atau sebelum dilakukan penanaman bibit bawang merah. Pupuk disebar di atas bedengan, kemudian diaduk merata dengan tanah. Jenis pupuk yang digunakan adalah NPK Mutiara dengan takaran 16:16:16, sebanya $500 \mathrm{~kg}$, dan SP 36 sebanyak 50$100 \mathrm{~kg}, \mathrm{KCl} 30-60 \mathrm{~kg}$ untuk dosis aplikasi per hektare. Untuk pemupukan pertama ini jika menambahkan pupuk kompos atau pupuk kandang, dosis NPK Mutiara (16:16:16) dapat dikurangi menjadi $250 \mathrm{~kg} / \mathrm{ha}$. Alasan penggunaan pupuk ini adalah karena unsur $\mathrm{P}$ dan $\mathrm{K}$ sulit larut sehingga perlu waktu (minimal 14 hari) agar unsur tersebut dapat diserap tanaman. Pada umur tujuh hari akar tanaman bawang mulai tumbuh dan membutuhkan unsur tersebut untuk perkembangannya. Unsur P dan K dari NPK, SP 36 dan $\mathrm{KCl}$ akan tersedia bagi tanaman sepanjang pertumbuhan bawang merah. Selanjutnya, pemupukan susulan pertama diberikan saat tanaman berumur 10-15 hari dengan jenis pupuk Urea dengan takaran $180 \mathrm{~kg} / \mathrm{ha}$ atau ZA 400 $\mathrm{kg} / \mathrm{ha}$. Pemupukan ini bertujuan untuk memberikan cadangan makanan bagi umbi karena pada umur 15-30 hst cadangan makanan umbi cepat habis, sehingga perlu unsur $\mathrm{N}$ dan $\mathrm{S}$ untuk 
pembentukan daun, batang, dan akar. Pupuk susulan kedua diberikan saat tanaman berumur 3035 hst dengan jenis pupuk Urea $180 \mathrm{~kg} /$ hektare. Pada umur-umur ini tanaman memasuki fase pembentukan umbi, sehingga memerlukan karbohidrat hasil fotosintesis sebagai bahan pembentukan umbi. Unsur $\mathrm{N}$ dari Urea digunakan dalam proses fotosintesis untuk pembentukan karbohidrat (https://8villages.com/full/petani/ article/id/5aaa368f60c977b33b1b28b6), dikunjungi pada 28 September 2019). Dengan demikian, jelas bahwa budi daya bawang merah membutuhkan banyak pupuk buatan agar tanaman tersebut tumbuh dan berkembang, serta sukses dalam panennya. Kondisi itu yang menyebabkan kebutuhan pupuk buatan pada budidaya bawang merah semakin besar. Dengan kata lain, petani kini sulit lepas dari pupuk buatan.

Bersamaan dengan itu, ada berbagai kemudahan untuk mendapatkan pupuk buatan maupun pestisida anti-hama di wilayah pedesaan. Banyak toko pupuk dan pestisida yang secara khusus menjual sarana produksi tersebut. Lebih dari itu, agen distributor pupuk buatan dan pestisida antihama juga masuk hingga pedesaan. Mereka gigih menawarkan barang jualannya. Dalam memasarkan produknya, mereka memakai beragam cara agar pihak toko giat menjual barangnya, mulai dari memberikan diskon harga hingga bonus penjualan jika sebuah toko dapat menjual lebih dari target yang ditentukan. Para agen pupuk buatan dan pestisida punya cara tersendiri dalam memasarkan produk langsung ke petani. Salah satunya, mereka dibujuk dengan menggunakan aneka hadiah, misalnya kaos. Cara lainnya adalah dengan memasang spanduk di suatu lahan yang tanamannya terlihat tumbuh dengan subur. Spanduk itu biasanya berisi informasi bahwa lahan itu memakai produk tertentu, dalam hal ini adalah produk pemilik spanduk. Dengan cara itu, pupuk buatan dan pestisida dipasarkan secara luas hingga pelosok pedesaan, termasuk di pedesaan Brebes.

Pihak produsen pestisida sedikit banyak diuntungkan oleh kebiasaan petani bawang merah yang selalu menggunakan pestisida dalam upaya memerangi hama tanaman. Dengan kata lain, petani bawang merah tidak perlu lagi diyakinkan untuk memakai pestisida. Dalam pemikirannya sudah tertanam keyakinan bahwa tanpa pestisida antihama tanamannya akan gagal panen karena diserang hama perusak tanaman. Dengan kondisi itu, pihak distributor pestisida antihama tidak memerlukan banyak upaya untuk memasarkan produknya. Mereka biasanya memberi contoh mengenai keberhasilan seorang petani yang memakai produknya dalam upaya memerangi hama penganggu tanaman. Dalam hal ini, biasanya petani yang memakai produk pestisida dari distributor tertentu, mereka mendapat hadiah terlebih dahulu. Dengan cara itu, ketika ada petani lain bertanya mengenai pestisida yang digunakan, maka petani tersebut langsung merujuk pada produk pestisida tertentu, dalam hal ini yang telah memberi hadiah kepadanya.

Program modernisasi pertanian dalam revolusi hijau tidak hanya memberi pengaruh positif terhadap petani dan hasil pertaniannya, tetapi juga memberikan pengaruh negatif yang bersifat langsung maupun tidak langsung, salah satunya berdampak pada aspek kesehatan yang selalu tidak disadari. Mereka merasa dengan memakai kedua Saprodi itu tanaman bawang merah produksinya akan meningkat, sehingga mereka tidak mengalami kerugian. Satu hal yang tidak mereka sadari adalah volume penggunaannya semakin lama semakin bertambah, yang kemudian menyebabkan biaya produksi meningkat. Dampak negatif tersebut telah berlangsung selama bertahun-tahun dan bersifat gradual, sehingga tidak pernah disadari oleh para petani. Petani meneruskan segala macam perbuatan dan kebiasaan orang tua mereka dalam budi daya bawang merah. Oleh karena itu, mereka tidak pernah menyadari pengaruh negatif penggunaan pupuk buatan dan pestisida. Petani bawang merah juga merasa tidak setiap obat antihama manjur untuk mengatasi serangan serangga penggangu tanaman bawang merah, sehingga mereka kerap melakukan uji coba aneka obat-obatan baru; tidak jarang mereka mencampur dengan berbagai macam pestisida. Mereka tidak menyadari bahwa semakin lama hama tanaman semakin kebal terhadap pestisida antihama. Kebiasaan itu tetap 
dilakukan tanpa menyadari bahwa unsur hara dalam tanah semakin tidak seimbang, karena penggunaan pupuk yang semakin banyak. Oleh karena itu, jenis pupuk yang digunakan semakin lama semakin banyak.

\section{PERUBAHAN SISTEM BAGI HASIL DALAM BUDI DAYA BAWANG MERAH}

Terdapat beberapa perubahan penting dalam budi daya bawang merah, khususnya dalam hubungan antara petani pemilik tanah dan penggarap. Pertama perubahan itu terkait dengan kepemilikan lahan pertanian. Petani bawang merah adalah pekerjaan yang bersifat turun-temurun. Pada banyak kasus terdapat fragmentasi lahan pertanian. Akan tetapi, terdapat pula kasus bahwa anak petani bawang merah tidak lagi mampu meneruskan pekerjaan orang tuanya. Mereka kemudian menyewakan atau melakukan bagi hasil atas lahan budi daya bawang merah dalam sistem sewa lahan. Dengan kata lain, hasil lahan pertanian hanya merupakan pendapatan tambahan bagi mereka. Sementara itu, dengan perkembangan pendidikan yang mampu menjangkau ke pelosok pedesaan menyebabkan terjadi perubahan pemikiran dan pandangan hidup generasi muda pada masa sekarang. Mereka tidak lagi menginginkan bekerja sebagai petani. Pekerjaan di kota dianggap jauh lebih bergensi dibandingkan hanya menjadi buruh tani di desanya. Oleh karena itu, tidak mudah mendapatkan buruh tani yang berasal dari generasi muda. Tenaga kerja di bidang pertanian menjadi semakin langka, karena dianggap tidak menarik dan bergengsi bagi generasi muda.

Perubahan yang terjadi di kalangan generasi muda itu secara tidak langsung mempengaruhi persentase bagi hasil antara pemilik lahan dan penggarap. Kondisi itu masih ditambah dengan peniingkatan ongkos produksi budi daya bawang merah yang menyebabkan peningkatan risiko yang harus ditanggung oleh petani penggarap. Biaya produksi meningkat akibat volume dan harga pupuk buatan yang terus bertambah, menjadi beban yang harus ditanggung penggarap. Hal itu masih ditambah dengan risiko gagal panen karena serangan hama. Semua kondisi itu menyebabkan perubahan dalam sistem bagi hasil pada budi daya bawang merah.

Penerapan teknologi pertanian dijalankan seorang pemilik lahan yang akan menerima satu bagian hasil panen, sedangkan penggarap lahan menerima tujuh bagian hasil panen. Sistem bagi hasil itu dikenal sebagai mara wolu (bagi hasil 1:7). Dalam sistem itu, semua biaya ditanggung pihak penggarap lahan, sedangkan pemilik lahan tidak terlibat sama sekali. Mereka hanya menerima hasil panen. Sistem bagi hasil tersebut saat ini sudah tidak lagi dilakukan. Para penggarap tidak menerapkan sistem tersebut karena biaya yang harus ditanggung dan risiko gagal panen semakin meningkat. Mereka menghendaki sistem mara sepuluh (bagi hasil 1:9), dengan ketentuan satu bagian didapatkan oleh pemilik lahan, sementara sembilan bagian didapatkan oleh petani mara yang memanfaatkan lahan dan menanggung semua biaya produksi dari masa awal tanam sampai panen (Wawancara dengan Sunarsih dan Muslihin, 21 Juli 2019). Pembagian hasil dari sistem mara ini biasanya dilakukan setelah masa panen, setelah penjualan hasil panen, bisa dalam bentuk barang maupun uang (Wawancara dengan Maulana, 21 Juli 2019). Dengan demikian, jelas terlihat bahwa adanya penerapan teknologi pertanian yang diperkenalkan dalam Revolusi Hijau menyebabkan persentase hasil panen penggarap lahan meningkat. Hal itu disebabkan ongkos produksi dan beban resiko yang harus mereka tanggung juga meningkat.

Pemilik lahan bersedia mengurangi persentase pendapatannya karena dua hal. Pertama, mereka merasa tidak menanggung risiko gagal panen. Dalam sistem bagi hasil mara wolu yang berubah menjadi mara sepuluh, pemilik lahan hanya menyediakan lahan pertaniannya saja. Tidak ada kewajiban lain yang harus ditanggung pemilik. Oleh karena itu, mereka merasa tidak menanggung kerugian jika terjadi gagal panen. Penggarap merupakan pihak yang menanggung risiko jika terjadi gagal panen. Kedua, posisi keuangan yang tidak lagi bertumpu di lahan pertanian. Mereka kebanyakan tidak lagi tinggal di desa, tetapi pindah di wilayah perkotaan. Mereka tidak mempunyai waktu untuk mengawasi apalagi mengerjakan lahan pertaniannya. Mereka kemudian mencari 
pihak yang bersedia mengerjakan lahan pertaniannya dengan sistem bagi hasil. Kondisi ini jelas menunjukkan bahwa lahan pertanian yang dimiliki pemilik tanah, yang merupakan warisan orang tuanya, bukan merupakan sumber pendapatan utama melainkan tambahan. Oleh karena itu, mereka sudah merasa beruntung jika lahan pertaniannya memberikan hasil panen, meskipun hanya sedikit dan jauh berkurang dibanding pada masa sebelumnya.

\section{SIMPULAN}

Sistem budi daya bawang merah di Brebes tidak dapat dilepaskan dari adanya Revolusi Hijau. Melalui sistem budi daya baru dalam tanaman bawang merah, petani mengenal berbagai macam pupuk buatan dan pestisida. Mereka meninggalkan sistem budi daya lama yang memakai cara tradisional dalam menanam tanaman bawang merah. Semuanya itu tanpa disadari oleh petani bawang merah telah membawa perubahan dalam sistem budi daya bawang merah. Perubahan itu terjadi pada dua hal. Pertama, cara budi daya yang mengutamakan pada penggunaan beragam pupuk buatan/kimiawi serta pestisida dengan volume penggunaan yang semakin lama semakin besar. Dengan demikian, budi daya bawang merah di Brebes juga semakin terkapitalisasi karena biaya produksi semakin tinggi yang disebabkan oleh peningkatan kebutuhan pupuk dan pesitisida untuk menekan produktivitas lahan. Bersamaan dengan itu, mereka membutuhkan dana yang tidak sedikit untuk membeli pestisida agar tanamannya terbebas dari hama. Semuanya itu membutuhkan banyak modal untuk membiayai budi daya bawang merah.

Adanya kapitalisasi dalam budidaya bawang merah yang semakin lama semakin mahal itu secara tidak langsung berdampak dalam sistem bagi hasilnya antara pemilik lahan dan penggarap. Penggarap menjadi pihak yang harus menanggung beban biaya produksi lebih besar akibat peningkatan volume penggunaan pupuk dan pesitisida. Kondisi itu mengubah sistem bagi hasil dalam budi daya bawang merah. Sebelumnya, pemilik mendapat satu bagian, sedangkan penggarap memperoleh tujuh bagian, tetapi dengan kondisi ini berubah. Dengan kondisi semua biaya produksi ditanggung oleh penggarap lahan, maka penggarap meminta bagiannya ditambah. Penggarap pada masa sekarang mendapat sembilan bagian hasil panen, sedangkan pemilik lahan hanya satu bagian hasil panen. Dengan kata lain, mara wolu berubah menjadi mara sepuluh.

\section{REFERENSI}

Abdullah, I. et al. (1995). Kesempatan Kerja dan Perdagangan di Pedesaan. Yogyakarta: Pusat Penelitian Kependudukan UGM.

Arndt, H. W. (1994). Pembangunan Ekonomi Indonesia, Pandangan Seorang Tetangga. Yogyakarta: Gadjah Mada University Press.

Bank Indonesia (2001). Sejarah Peranan Bank Indonesia Dalam Pengembangan Usaha Kecil. Jakarta: Biro Kredit Bank Indonesia.

Bank Negara Indonesia Unit I, Laporan Tahun Pembukuan 1966/1967

Booth, A. (1988). Agricultural Development in Indonesia. Sydney: Allen \& Unwin.

Burger, D. H. (1962). Sejarah Ekonomis Sosiologis Indonesia I. Jakarta: Pradnja Paramita.

Collier, William L. Soentoro, Gunawan Wiradi, Effendi Pasandaran, Kabul Santoso, Joseph F. Stepanek (1982). "Acceleration of Rural Development in Java”. Bulletin of Indonesian Economic Studies Vol. 18 (3): 84-101. https://doi.org/10.1080/0007491 8212331334230

Gottschalk, L. (1975). Mengerti Sejarah (terjemahan Nugroho Notosusanto). Jakarta: Universitas Indonesia Press.

Hartono, S. (1996). Kredit Pertanian Dalam Program Intensifikasi Padi Yogyakarta: Makalah dalam Seminar Bulanan Pusat Penelitian Pembangunan Pedesaan dan Kawasan pada 1 Februari 1996.

Humas BRI, (1995). Seratus Tahun Bank Rakyat Indonesia 1895-1995. Jakarta: Kantor Pusat Bank Rakyat Indonesia. 
Garraghan, G.J. (1957). A Giude to Historical Method. New York: Fordham University Press.

Jones, G. W. (1984). "Links Between Urbanization and Sectoral Shifts in Employment in Java". dalam Bulletin of Indonesian Economic Studies Vol. $20 \quad$ (3): 120-157. https://doi.org/10.1080/00074918412331 334722

Kartodirdjo, S., Djoko Suryo (1991). Sejarah Perkebunan di Indonesia, Kajian Sosial Ekonomi. Yogyakarta: Aditya Media.

Kompas, 28 Februari 1978.

Notosusanto, N. (1978). Masalah Penelitian Sejarah Kontemporer. Jakarta: Inti Idayu, 1978.

Pranoto, Suhartono W. (2014). Teori \& Metodologi Sejarah. Yogyakarta: Graha Ilmu.

Rahardjo, M. D. (1984). Transformasi Pertanian, Industri dan Kesempatan Kerja. Jakarta: UI Press.

Sajogyo, S. (1977). "Golongan Misikin dan Partisipasi Dalam Pembangunan Desa”. Prisma Tahun IV No.3.

Sangging, Made Puri Adnyani (1990). Peranan Koperasi Unit Desa (KUD) Sebagai Penyalur Kredit BIMAS di Kabupaten Gianyar. Denpasar: Laporan Penelitian Tidak Diterbitkan.

SK. Menteri Pertanian No. 546/Kpts/12/org/ 1969.

Staub, W.J. (1977). "Kredit Produksi di Kalangan Petani di Jawa". Prisma, Vol. IV (7).

Sujono, I. dan Achmad T. Birowo (1976). "Distribusi Pendapatan di Pedesaan Padi Sawah di Jawah Tengah”. Prisma, Vol.V (1).

Syamsudin, A. B. dan Hasrida (2019). "Pemberdayaan Petani Bawang Merah terhadap Kesejahteraan Keluarga Kolai Kabupaten Enrekang". Jurnal Mimbar Kesejahteraan Sosial, Vol. 2 (1): 1-12.

Temple, G. P. (1976). "Mundurnya Involusi Pertanian: Migrasi, Kerja dan Pembagian Pendapatan di Pedesaan Jawa”. Prisma, Vol. $3(5)$.

Tjipropranoto, P. (1977). ”Beberapa Aspek Sosial Pembangunan Pertanian: Petani dan

\section{Pembangunan Pertanian.” Ekonomi \\ Keuangan Indonesia, Vol. 15 (3).}

\section{DAFTAR INFORMAN}

Sunarsih, petani bawang merah.

Muslihin, petani bawang merah.

Maulana, petani bawang merah.

Wage, petani bawang merah. 